\title{
Television in Young Children's Social Relationships
}

\author{
MIRA ROINE, M.Soc.Sc., Researcher \\ SATU VALKONEN, M.Soc.Sc., Researcher \\ ANJA RIITTA LAHIKAINEN, Professor, project leader \\ Department of Sociology and Social Psychology \\ University of Tampere, Finland
}

\begin{abstract}
Our aim is to highlight the role played by television in pre-school-aged children's social relationships. We moreover examine how social relationships are related to children's capabilities to cope with their television fears.
\end{abstract}

Children aged 5 to $6(N=309)$ were interviewed in three Finnish university cities using previously developed interview methods. Parents $(N=297)$ completed four questionnaires covering family background, TV viewing habits, psychiatric well-being and quality and quantity of the child's sleep.

Television viewing by pre-school-aged children was quite social in nature, although our qualitative data suggested that television was sometimes also used in asocial ways. Co-viewing within the family was common, whereas peer group's significance in the media reception process was evident after the viewing situation, in children's games based on television programs. $62 \%$ of children reported at least one television fear. However, it seems that the presence of family members may help children to cope with television fears.

Keywords: Television, children, social relationships, television fears

\section{Introduction}

In today's western industrialized societies, the media play a prominent role in everyday life, and their importance continues to grow. Children acquire much of their knowledge of the world through the media. (Süess et al. 1998, 522.) As far as very young children are concerned, television is extremely important. Television is said to be a significant medium for pre-school-aged children, mainly because they can use it independently, without parental supervision. Moreover, accessing this medium, and in contrast to many other media, neither the ability to read nor advanced motoric skills are necessary. For instance, young children may have difficulties in playing certain types of complex computer games on their own. (See Suoninen 2004, 104-109.) In 
this article, we decided to concentrate essentially on an analysis of television rather than focusing on other, more sophisticated media, because, as many previous studies indicate, television is the most used medium among children of all ages. Indeed, in Europe, almost every child has access to a television and can use it frequently, most often daily (Süess et al. 1998; Beentjes et al. 2001; Suoninen 2001; Carlsson and von Feilitzen 1998).

Although Finland is known worldwide as a laboratory of information society (Suoranta and Lehtimäki 2004) and a pioneer in new technologies, Finnish people, just like other Europeans, tend to focus heavily on television (Livingstone et al. 2001). One reason for the enduring popularity of television is its capability to renew itself (ibid; see also Valkonen et al. 2005). Also, as digital technology continues to develop, the position of television as the main medium of everyday life may in fact be further enhanced: it may serve as the base on which other media, such as game consoles, DVD players, or even the Internet, are combined (Suoranta and Lehtimäki 2004, 21).

For years, parents, educators and social commentators have reiterated that television viewing, as well as other forms of media consumption can be harmful to children (about this debate, see Buckingham 1993, 6-9; Rönnberg 1997; Hadley and Nenga 2004; Viemerö 1986). People seem to be worried about children's use of the media, especially when they spend much time on their own and do not have many social contacts (compare to Kytömäki 1999, 95; Matikkala and Lahikainen 2005). However, previous studies on children's use of television have noted that many children in fact use this medium in social ways (ibid.; Suoninen 2001; 2004; Lull 1990). This discrepancy between public debate and empirical studies demonstrates that more detailed research on the social aspects of children's use of television is necessary.

\section{The focus of the article}

Our aim is to highlight some of the ways in which television pervades pre-school-aged children's social relationships. Excessive TV viewing has previously been associated with many negative outcomes in children's social development and health, such as aggressive behavior (Robinson et al. 2001), attention problems and hyperactivity (Christakis et al. 2004; Ozmert et al. 2002), some somatic problems (Toyran et al. 2002) and social problems (Ozmert et al. 2002), for example, family interaction problems (Bernard-Bonnin et al. 1991).

Although the extent of children's television use has been widely demonstrated as harmful, remarkably little work has concentrated on the factors that determine it. However, one noteworthy predictor of television use is children's age (Anand and Krosnick 2005). Almost all studies demonstrate that television viewing increases up to the beginning of adolescence (Beentjes et al. 2001, 87). These findings seem 
obvious, because as children grow older, they stay up longer and are interested in more programs. Moreover, parents give older children more freedom with regard to their media choices (Kytömäki 1999).

In contrast to many earlier studies (see e.g. Buckingham 1994), we will here emphasize the social and contextual aspects of media reception processes. By so doing, we shall be able to examine the role of television in children's everyday lives at home and the implications of television-related experiences for children's well-being.

Before concentrating on the social aspects of television viewing, we look at the time children spend watching television and the types of programs they actually watch. After describing these we suggest some ways in which television influences young children's social relationships. We also examine how social relationships are related to children's capabilities to cope with their television-induced fears. We will begin by presenting our data and then proceed to consider the role of the television screen in young Finnish children's social lives.

\section{Data}

\section{Participants}

A population-based random sample was collected in three university cities (Helsinki, Tampere and Kuopio) in Finland as a part of the project 'Children's Well-being and Media in Societal and Cultural Contexts' (funded by the Academy of Finland). The sampling frame consisted of 428 children born between 1 January 1997 and 31 December 1998, representing the mainstream urban population of 5 to 6-year-old children in three Finnish cities. First, a letter was sent to all parents in the spring 2003 describing the research frame and also inviting the parents to inform their child about our study. Parents were then contacted by phone and asked whether they would participate in the research. Children's willingness to participate was also confirmed. We failed to reach 64 of the families by phone and 33 families refused to participate. Ten cases were excluded from the study due for instance, to serious handicap or severe parental alcohol problems. Questionnaires were sent to 331 families. 24 recipients did not return the questionnaires despite reminders. Hence, we had a total of 297 consenting families giving a response rate of $81.6 \%{ }^{1}$. The proportion of participating children was even higher: we interviewed 12 children whose parents did not return the questionnaires. Therefore, in total, 309 children were interviewed.

${ }^{1}$ The response rate is based on the net sample size (428-64=364) 
As regards socio-economic status, $32.4 \%$ of the mothers and $47.0 \%$ of the fathers were in the lowest SES group (had not graduated from upper secondary school), 31.9\% of the mothers and $21.5 \%$ of the fathers were in the intermediate group (some lower qualifications or matriculation examination only) and $35.7 \%$ of the mothers and $31.5 \%$ of the fathers were in the highest SES group (academic degree). $80.4 \%$ of the parents were either married or cohabiting. There were 138 (46.5\%) girls and 159 (53.5\%) boys in the sample. At the time of the interview, $78.6 \%$ of the children were in day care (either in a day-care center or in children's private day care).

\section{Measures and methods}

Parents - one or both - completed four questionnaires covering family background, TV viewing habits, psychiatric well-being and quality and quantity of the target child's sleep.

Our semi-structured interviews with children were based on previously developed interview methods (see Lahikainen et al. 1995; 2003). Interviews were conducted in the child's day-care center or at home. In addition two children were interviewed in the researcher's workplace. All the children were interviewed individually. On this research project children's capacity to express their thoughts about television and their well-being is of the essence. Therefore a multi-strategic interview method to enhance children's opportunities to act as informants of their own lives was used (see e.g. Christensen and James 2000). Using a variety of techniques is often seen as an effective way to make interviews interesting for young children. It is also a successful strategy for collecting valid and relevant data. (See Punch 2002.)

At the beginning of the interview we asked the children to create their social network in the form of a target diagram (see ibid.; Phillipson 2004). We also asked them about their fears using both open-ended questions and picture-aided questions. The intensity of fear was measured using three different categories (great, average and minimal fear) (Carpenter 1990). Nightmares and children's opinions regarding television were also main themes in the interviews. (A more detailed description of the interview outline can be found in Appendix I.)

\section{Results}

As previously mentioned, we are committed to an approach that takes into consideration contextual elements of children's media use. Against this background, it is appropriate to start by describing the media environment of Finnish children today. Here we rely mainly on the data gathered from the parents, because even school-aged children are perceived as too young to estimate, for instance, the amount of time they spend watching television in a day (e.g. Kytömäki 1999, 97). However, when possible, we also take account of children's own perspectives on the phenomena of interest. 


\section{The TV-Screen in young Finnish children's lives: how much and what?}

According to our findings, 5 to 6-year-old children watched TV on average 1.2 hours a day on weekdays and slightly more at weekends: approximately two hours on both Saturdays and Sundays (the questions related to this study are presented in Appendix II). This gives an average of about ten hours a week. Because research on television viewing by children this young has been quite scarce, there are not many studies that are fully comparable with ours (see also Lahikainen et al. 2004; Kytömäki 1999, 7). For instance, Beentjes et al. (2001) discovered in their study that Finnish children watch television for about 17 hours a week. However, their study focus concerned older children, aged 9 to 16 . These results cannot therefore be used s as a basis for direct comparison.

In the families in our sample, the television was on during the target child's waking hours on average 2.7 hours a day. However, in total television was on in the families for an average of 3.8 hours a day. Every family had at least one television set, and on average there were two TVs in the household. According to the parents' reports (parental questionnaires, see Appendix II), a majority (89.1\%) of the children watched children's programs often (3-5 times a week) or daily. Watching videos was common, too: $39.5 \%$ of the children watched videos often or daily. Some children, however, also watched current affairs programs (20.1\%), adult TV series (20.2\%) and sports (30.0\%) quite regularly (with answers ranging from 'sometimes (1-2 times a week) ' to 'always (daily)' in the questionnaires).

The prominent status of children's programs is hardly a surprise. Parents let their offspring watch children's programs whereas many other programs are presumably forbidden. However, our child interviews indicate that many children did not even want to watch such programs that they thought were meant for adults. One reason for this could be that young children tend to identify with characters similar to them, that is, with other children. It has been suggested that Scandinavian programming for children provides many opportunities for such identification. (von Feilitizen and Linné 1975; compare to Merlo-Flores 1998; Kodaira 1998, 96.)

Some previous studies (e.g. Anand and Krosnick 2005; Beentjes et al. 2001, 88) have demonstrated that boys watch more television than girls, but we could not establish any association between child's gender and frequency of media use: the boys in our sample did not generally watch TV more than the girls. Nevertheless, watching sports and playing video games were associated with children's gender: boys both watched sports $\left(\mathrm{Chi}^{2}=33.2 ; \mathrm{df}=1, \mathrm{p}<.001\right)$ and played video games $\left(\mathrm{Chi}^{2}=13.5 ; \mathrm{df}=1 ; \mathrm{p}<.001\right)$ more often than girls. Both of these tendencies are widely recognized as masculine, which implies that gender stereotypes start to play an important role regarding children's media choices at an early age (see also Lehtimäki and Suoranta 2005). 


\section{With others or alone}

Children's surroundings nowadays contain an increasing number of media-cultural devices and their daily lives are affected by the use of these technologies (Suoranta and Lehtimäki 2004). The growing number of media technologies results, for example, in such phenomena labeled as the privatization of bedrooms (Pasquier 2001; Pasquier et al. 1998; Bovill and Livingstone 2001). As more and more families have several television sets (e.g. Suoranta and Lehtimäki 2004), solitary viewing has become increasingly common. At the same time, the presence of several television sets in the household challenges parents' abilities to control their offspring's viewing habits.

According to the parental questionnaires, 58.1\% of the children watched television alone either sometimes or often. Co-viewing with other family members was anyhow more common: most parents (74.5\%) said that they watched television with the target child sometimes or often. Only in one particular family, did the parents report never watching TV with their child. Co-viewing has been demonstrated to increase further when children get older, since it becomes easier to find suitable programs for all the family (Kytömäki 1999).

However, as many children have the opportunity to access television while alone, they may occasionally watch a program that is meant for adults. As a result, some mediated messages may generate fear in them and also threaten their sense of well-being. (Valkonen et al. 2005; Lahikainen et al. 1995, 50.) Moreover, many parents may be unaware of their children's frightening media experiences because of the family's individualized television viewing habits. We will look at these issues more closely later in this article.

In our study, $20.9 \%$ of children had a TV-set in their own rooms which concurs with d'Haenens' results. He found that $21 \%$ of 6-7-year-old Finnish children have a television set in their bedrooms. This increases when the child gets older. (d'Haenens 2001, 58.) According to our findings, children who had a television set in their bedrooms watched television more often alone than did the other children $\left(\mathrm{Chi}^{2}=8.6\right.$; $\mathrm{df}=1$, $\mathrm{p}<.005$ ) (see Table 1 below). According to parents' reports (question 16, see Appendix II), children with a TV-set also tended to watch television or videos more often at bedtime $\left(\mathrm{Chi}^{2}=11,9 ; \mathrm{df}=1, \mathrm{p}<.005\right)$. Of all the children in the study, $29.8 \%$ watched TV or videos at bedtime (occasionally or more often). The presence of a TV-set in the child's room was elicited with the parental question 'The child has a TV-set in her/his room: Yes/No'. The phrasing of the question thus indicates that some children may not actually possess an individual TV-set but rather share the apparatus with their siblings who are sharing a bedroom with them. 
Table 1. Connections between the child's solitary viewing and own TV-set. Note: $\mathrm{N}=297$, percentages based on valid responses.

\begin{tabular}{lccc}
\hline & \multicolumn{3}{c}{ Child has a TV set in bedroom } \\
Child watches TV alone & Yes & No & Total \\
\hline Seldom/ never & 20.0 & 40.4 & 36.2 \\
& & & 63.8 \\
Sometimes/ often & 80.0 & 59.6 & \\
& & & 100.0 \\
Total \% & 100.0 & 100.0 & 290 \\
Total N & 60 & 230 & \\
\hline
\end{tabular}

As Vandewater et al. (2005) found, the presence of a television in the child's own room increases the odds of a child living in a household where television is on for long hours (see also Bovill and Livingstone 2001). We were able to establish a parallel association: in the families where the child had a TV-set in her/his bedroom, television was on significantly more both on weekdays $(\mathrm{p}<.01)$ and at weekends $(\mathrm{p}<.001)$, and the amount of TV viewing of the target child was also higher than that of children in other families ( $\mathrm{p}<.001)$ (see Appendix III).

In the questionnaire we also asked parents to estimate how often the target child watched television with her/his peers (either friends or siblings). It has been stated in previous studies that young children's lives are mainly centered on the home and family, and that their uses of the media mostly take place within the family context (Süess et al. 1998, 535). However, peer group relations are of the essence in children's media use as well. This is especially true in Finland, where the culture has been characterized as peer-oriented. According to findings presented in the study by Suoninen (2001, 202-205), Finnish children (aged 6 to 7 and 9 to 10) had, for example, fewer restrictions on going out than children in some other European countries. Besides that, fewer than one third of Finnish children spent their leisure time mostly with their family. This was in sharp contrast to family-oriented cultures (e.g. Spain and Italy), in which more than half of the children spent their leisure time with the family. (Ibid.) In line with this background, it seems reasonable to suggest that as many as $52.2 \%$ of the children in our study watched television with their peers quite often (answers ranging from 'sometimes (1-2 times a week)' to 'often (3-5 times a week)').

Furthermore, the social nature of television may become evident apart from the viewing situation. Because preschool children's actual media use is often within the family context, peer group significance in the media reception process takes a major place afterwards through role-plays, games or other activities (Suoninen 2001, 216-217; Kalliala 1999). Talking about media is the most important way in which media affect peer group and other social relationships (Kytömäki 1999). Among preschoolers, television-related talk 
emerges mostly in play, when children develop role-plays based on television programs or movies (Suoninen 2001). The next extract illustrates this situation:

(C=Child)

C: We played one funny game which we have made up by ourselves here in kindergarten. We are playing a game called Scoopy Doo with Eero and my little brother. - I am Scoopy Doo and Eero is the kind of little dog and Kasper is called Lyyri Lyy..oh no...Lyyli Lyy.

Children display their media knowledge when playing and acting together. Televisionrelated play can be seen as an essential part of children's media reception process and thus an important component of children's relationship to TV. Play may draw ideas directly from cartoons or other programs, but sometimes its origins are less clear. Children may combine parts from different programs as well as from real life and create their own variations. (Ibid.) The outcome is their own achievement as the extract above demonstrated. On the other hand, children may sometimes apply television contents in less constructive ways in their social relationships:

(I=Interviewer, $\mathrm{C}=$ Child)

I: Have you ever learnt anything from TV? Or skills?

C: No. I just learn from Digimon.

I: What are you...?

C: Greymon's stunts, flying, Greymon's stuntflying, Gargurumon's punching,

killing Patamon and Patamon...no, Kabuterimon's flying...fighting.

I: That's what you've learnt.

C: Yes. And Ikkamon's water squirts.

I: Mmm, aren't those kind of, fighting things. What have you done with these skills?

C: Eeh, fighting.

I: You've been fighting...?

C: Yes.

I:...here in kindergarten?

C: No, not here, but at home.

This extract suggests that media induced action models which we adults find negative, may express themselves in children's social activities. However, it should be emphasized that young children do not simply internalize and reproduce the ideas received from the television screen. By contrast, children actively integrate moving images seen on TV into their peer relations through thought and action. (See Hadley and Nenga 2004.) Mediated action models may assume many different forms in children's activities and thus it is hard to say how damaging the given model ultimately is. A lot depends on how and why the mediated model is used and what consequences media induced action has. 
Moreover, our qualitative data implies that television may - in some circumstances - be used to replace friends and other social relations (see Rosengren and Windahl 1989; compare to Matikkala and Lahikainen 2005). The extract below sheds light on this:

I: Well, do you have any other close friends when you are not here in day care?

C: Uhmm, you mean at home?

I: Yes.

C: No, I don't think so, other than watching videos.

Though this extract may suggest that television programs - or more precisely videos ${ }^{2}$ - take, at least partly, the place of social relationships in the life of this child, it is impossible to draw direct conclusions on the extent of this child's social network on the basis of this extract. We think it is more reasonable to assume that children's relationship to the media becomes pernicious only when the media occupy a major role in their lives, mostly at the expense of human relationships. In order to conclude that some children regularly use television in asocial ways, we should obtain additional information, for example, on their daily routines and social interaction habits.

On the whole it seems that television may have both positive and negative outcomes in children's social lives. As noted, children do not simply reproduce television contents in their games and action but actively interpret each television mediated message in the way that best fits the child's situation at that moment. The child's personality, the form of media and viewing situation as well as other contextual elements define what exact form the media content will be given in the interpretation process. What is noteworthy is that this sense-making process is usually social, at least to some extent. For instance, television may be viewed together and hence the social viewing situation affects how the television mediated images are interpreted. On the other hand, interpretation may be complemented afterwards in children's play or discussions within family (see also Suoninen 2001; 2004).

\section{Social support in coping with television-related fears}

Although peer group is a significant aspect of the Finnish cultural context, the presence of parents or other significant adults whom the child is able to rely on in the TV viewing situation, is sometimes even more important. In the company of adults media contents that are hard to understand may become more accessible to children. For instance, when television evokes feelings of fear in the child, it matters whether there are caring adults nearby (see Kirmanen 2000a; 2000b; Korhonen and Valkonen, forthcoming).

${ }^{2}$ During the interviews we noticed that children did not differentiate between TV programs and videos. That is why these two are treated here synonymously. (See also Lahikainen et al. 2004.) 
A number of studies since the 1930s indicate that momentary fright responses to TV stimuli are quite typical and that enduring - and sometimes severe - emotional disturbances happen in a considerable amount of children (see Cantor 1994, 139). In our study $62 \%$ of the children reported at least one television-related fear in the interview (child was afraid to some degree or a lot).

It is often assumed that the more children watch television the greater their risk of seeing something frightening. Contrary to this statement, our results indicate that whether the child mentioned any television related fears or not was not associated with the amount of her/his television viewing. Presumably this has something to do with the quality of the Finnish public TV service, the channels' program policy and public control. The United States distributes most of the media violence in the world (von Feilitzen 1998, 45) and thus it seems reasonable to assume that the connection between time spent watching TV and the amount of television related fears would be much more evident there. However, it seems that some connections between excessive TV viewing and children's fright responses are present in Finnish culture, too. Our findings demonstrate that the number of all fears the child mentioned in the interview was positively connected with the hours spent watching television. This finding supports previous results obtained in the study by Gentile and Walsh (2002). They found that many negative effects of a given medium (for example TV) were related to the amount of time spent using it.

Although a majority of young children seem to have television fears, their parents are often unaware of them (e.g. Lahikainen et al. 1995; Lahikainen et al., forthcoming). Undoubtedly, one reason for parents being unaware of their children's television fears is that adults and children do not experience television in the same way. A child's understandings of television-related phenomena are always constructed from her/his own point of view. Thus it may be often highly unpredictable to adults what things seen on television can upset their children (Buckingham 1996, 88). The next extract illustrates this situation:

I: Do you watch any programs with the family, so that Mum and Dad are also there?

C: Mmm.. well that Emma gala we watched almost through, so, with our family.

I: Yes.

C: Even though there was that Lordi [Finnish rock musician], and he's quite scary.

I: Did you find it frightening?

C: Like a little, not much.

I: He is a little bit like... made himself of that kind...put on that kind of clothes.

C: Well yes... and Lordi won one award and as they came there, I was a little bit scared. 
The failure to distinguish between fiction and reality is here related to the child's fear. The ability to identify the special effects, for example the rock musician's scary makeup, would probably help the child in question to cope with the unpleasant aspects of the television viewing experience described above. (See ibid.) An important component of the development of fears is thus linked to the ability to understand the difference between fantasy and reality (Cantor 1994).

The social context of aforementioned viewing situation may also play some role in the child's experience (see Gentile and Walsh 2002, 160-161). Although the child may not tell about her/his fear to the parents, their presence probably helps the child to cope with the frightening TV viewing situation. Sometimes the use of social support is reported more explicitly:

I: Well, hmm, what do you do when those wildlife programs scare you?

C: Well then I go round Mum, to Mum, to Mum.

It has been found in earlier studies that especially girls lean on the social support of their parents when they try to cope with television-induced fears (see Kirmanen 2000a; 2000b). As described elsewhere (Korhonen and Valkonen, forthcoming), social support was also a very popular coping mechanism among the girls interviewed as a part of this research project.

However, television-related fears are not inevitably negative experiences for children. While a considerable part of children report they are sorry they have seen scary television programs because of the intensity of the fright reactions they have experienced (Cantor 1994), a number of studies has demonstrated that some children say that they enjoy being frightened and that they want to watch scary media (ibid., Buckingham 1993; 1996; Rönnberg 1997; Suoninen 1993) even if the viewing has unfavorable consequences:

I: What did you do when there were very scary parts?

C: I watched it anyway.

I: Oh.

C: But I had nightmares.

(Later in the interview:)

I: Do you have some favorite movie?

C: At least Star Wars.

I: Is it scary?

C: Yes, but anyway. I want to have nightmares.

I: Do you always have them after those scary movies?

C: Yes. 
This boy reports that he is willing to watch scary programs and that he even enjoys having nightmares. We may assume that such descriptions are possible only when there are caring adults available in the child's life. The child feels secure and thus dares to spread his wings in the world of ambiguous and even frightening media contents. Further, it may be assumed that because of this strong basic trust the child is also able to eliminate many fears by himself. (See Korhonen and Valkonen, forthcoming.) And if the scene suddenly changes to become too exciting, the child can always switch off the TV and join other family members.

\section{Conclusions and discussion}

The rapidly changing media environment has given rise to many debates related to the effects of the media on children. Excessive TV viewing as well as many other forms of media consumption are regarded as a threat to children's well-being. For instance, it is thought that television viewing both wastes children's time and excludes them from social contacts. In this last chapter we recapitulate some ways in which television pervades children's social relationships and what this implies for the children's social development and well-being.

Despite adults' concern about children's media use, media technology is anyhow within reach of children. That is because children do not nowadays live in isolated territories protected by their parents and caregivers. At first, privatization of media use at home challenges parents' abilities to control children's media consumption. In addition children may be exposed to continuous media flow in other places such as at their friends', day-care centres or public places such as shopping centres. (See Cantor 1998; von Feilitzen 1998; Lahikainen et al. 2004.)

The concern about children's increasing media consumption is not, however, totally unfounded. Excessive media use may indeed have negative outcomes in children's lives. For instance, as we demonstrated earlier in this article, children do apply media contents in their social interactions, and sometimes in less constructive ways. In addition our findings demonstrated that children who watched a lot of television, also reported a lot of fears in the interview. This may be due to the fact that television expands children's imaginative worlds beyond their concrete living surroundings (see Bronfenbrenner 1979, 47) and concurrently raises their awareness of frightening events which they otherwise would not know about. Therefore, children who watch a lot of television may also become aware of many possible sources of fear.

When discussing the consequences of children's media use, the analysis of the social context is of the essence. Indeed, social context is meaningful for children's abilities to cope with television-induced fears. When children are watching TV by themselves, it may sometimes be too difficult for them to make sense of different media contents. 
Our child interviews indicate that the company of caring adults is significant for children's sense-making processes. It seems to be important whether the child is obliged to interpret media alone or if is it possible to rely on parental company (see also Kirmanen 2000a; 2000b; Korhonen and Valkonen, forthcoming). The possibility of sharing frightening experiences with parents creates a secure atmosphere at home and thus enhances children's sense of well-being (Strasburger and Donnerstein 1999).

At the same time, co-viewing within family may have other positive consequences. For example, parents are able to maintain control over the television viewing situation and prevent their child from seeing undesirable media contents (see Strasburger and Donnerstein 1999). Besides that, co-viewing may provide parents with information on both positive and negative things that television mediates to their children's lives. Moreover, during co-viewing it is also possible for parents to encourage their children towards a media-critical attitude. We hence suggest that co-viewing, as well as other forms of social media uses within the family, could contribute to children's well-being in the present media culture.

It needs to be remembered, however, that solitary television viewing is not entirely harmful. Quite the contrary, it may also serve advantageous functions like encouraging the child's media literacy skills and independence from parents. And if children feel that they are capable of coping with television-induced fears by themselves, their sense of well-being may be further enhanced.

Besides the social aspects of the television viewing situation, there are other elements which probably play an important role in children's television use. At first, children differ from each other with regard to their media skills. Some children are more capable of making sense of ambiguous media contents than their age mates are. Consequently, not all children are frightened by given media messages. Furthermore, certain findings presented in this paper indicate that some children may try to calm down with television viewing. As we demonstrated in 4.2, a comparatively large proportion of children watch television at least occasionally at bedtime. Thus it seems reasonable that they find television viewing at bedtime relaxing. Whether the television viewing actually calms down those children, remains, however, largely unstudied. Moreover, some children may turn to TV (at bedtime or at other times) when parents are not available in order to get at least some kind of social contact in the form of parasocial interaction (see also Suoninen 2001, 202). In that study these issues were not of specific interest but we consider, however, that concentrating on this area would be important in future studies on the connections between children's well-being and media.

What this study recommends parents to do is to initiate more interaction between family members about the media use patterns of the whole family (see also Strasburger 
and Donnerstein 1999). Media-related experiences would also be worth discussing, because that way parents would become more aware of both positive and negative aspects of media perception in their children.

However, it needs to be pointed out that in Finland things are fairly positive. The public broadcasting here contrasts sharply with that in the United States, since it provides advertising-free and thus less commercialized children's programming (Buckingham 2002). The amount of television violence is also comparatively low in the Finnish television channels, again compared to American television, which distributes most of the media violence in the world (Beentjes et al. 2001; von Feilitzen 1998, 45). However, because Finnish parents tend to underestimate television as a fear-provoker (see Lahikainen et al. 1995; Lahikainen et al., forthcoming), it is important to further study television-mediated messages from the children's own perspectives.

To conclude, children live their everyday lives in a media-saturated culture where their experience of the world is enlarged by the development of media technology (see Bronfenbrenner 1979, 47). Although many adults tend to view technological development as potentially harmful, children grow up in this environment not knowing the world before the invention of TV, electronic games and the Internet. Children's development is in direct contact with current cultural values and it would in fact be quite surprising if they did not adopt ideas from television and other media in their actions and personal values. In this cultural context, many children may encounter TV-mediated benefits as well as threats without parental company. As we have demonstrated here, however, the TV viewing company of caring adults could contribute to children's well-being in the present media-saturated world.

\section{Acknowledgements}

We are grateful to the Academy of Finland for financial support for the research project 'Children's Well-being and Media in Societal and Cultural Contexts'. Mira Roine gratefully acknowledges the Emil Aaltonen Foundation and Satu Valkonen would like to thank the Alfred Kordelin Foundation for their financial support of our studies. 


\section{References}

Anand, Sowmya and Jon A. Krosnick. 2005. Demographic Predictors of Media Use Among Infants, Toddlers, and Preschoolers. American Behavioral Scientist 48(5):539-561.

Beentjes, Johannes W.J., Cees M. Koolstra, Nies Marseille and Tom H.A. van der Voort. 2001. Children's Use of Different Media: For How Long and Why? In: Children and their Changing Media Environment. A European Comparative Study, edited by Sonia Livingstone and Moira Bovill, pp. 85-111. Mahwah: Lawrence Erlbaum Associates.

Bernard-Bonnin, Anne-Claude, Sophie Gilbert, Elizabeth Rousseau, Pierre Masson and Brigitte Maheux. 1991. Television and the 3- to 10-year-old- child. Pediatrics 88(1):48-53.

Bovill, Moira and Sonia Livingstone. 2001. Bedroom Culture and the Privatization of Media Use. In: Children and their Changing Media Environment. A European Comparative Study, edited by Sonia Livingstone and Moira Bovill, pp. 179-200. Mahwah: Lawrence Erlbaum Associates.

Bronfenbrenner, Urie. 1979. The Ecology of Human Development. Experiments by Nature and Design. Massachusetts: Harvard University Press.

Buckingham, David. 1993. Children Talking Television. The Making of Television Literacy. London: Falmer Press.

---. 1994. Television and the Definition of Childhood. In: Children's Childhoods Observed and Experienced, edited by Berry Mayall, pp.79-113. London: Falmer Press.

---. 1996. Moving Images. Understanding Children's Emotional Responses to Television. Manchester: Manchester University.

---. 2002. Small Screens: Television for children. Leicester: London University Press.

Cantor, Joanne. 1994. Confronting Children's Fright Responses to Mass Media. In: Media, Children and the Family. Social Scientific, Psychodynamic and Clinical Perspectives, edited by Dolf Zillmann, Jennings Bryant and Aletha C. Huston, pp. 139-150. Hillsdale, New Jersey: Lawrence Erlbaum Associates.

---. 1998. "Mommy, I'm Scared”. How TV and Movies Frighten Children and What We Can Do to Protect Them. San Diego: A Harvest Original.

Carlsson, Ulla and Cecilia von Feilitzen. 1998. (editors) Children and Media Violence. Yearbook from the UNESCO International Clearinghouse on Children and Violence on the Screen. Göteborg: Göteborg University.

Carpenter, Paul J. 1990. New Method for Measuring Young Children’s Self-Reports of Fear and Pain. Journal of Pain and Symptom Management 5(4):233-240.

Christakis, Dimitri A., Frederick J. Zimmerman, David L. DiGiuseppe and Carolyn A. McCarty. 2004. Early television exposure and subsequent attentional problems in children. Pediatrics 113(4):708-14.

Christensen, Pia and Allison James. 2000. (editors) Research with Children: Perspectives and practices. London: Routledge Falmer.

Feilitzen, Cecilia von and Olga Linné. 1975. Identifying with Television Characters. Journal of Communication 25:51-55.

Feilitzen, Cecilia von. 1998. Introduction. In: Children and Media Violence. Yearbook from the UNESCO International Clearinghouse on Children and Violence on the Screen, edited by Ulla Carlsson and Cecilia von Feilitzen, pp. 45-54. Göteborg: Göteborg University.

Gentile, Douglas A. and David A. Walsh. 2002. A Normative Study of Family Media Habits. Applied Psychology 23:157-178.

Hadley, Kathryn Gold and Sandi Kawecka Nenga. 2004. From Snow White to Digimon. Using popular media to confront Confucian values in Taiwanese peer cultures. Childhood 11(4): 515-536. 
d'Haenens, Leen. 2001. Old and New Media: Access and Ownership in the Home. In: Children and their Changing Media Environment. A European Comparative Study, edited by Sonia Livingstone and Moira Bovill, pp. 53-84. Mahwah: Lawrence Erlbaum Associates.

Kalliala, Marjatta. 1999. Enkeliprinsessa ja itsari liukumäessä: leikkikulttuuri ja yhteiskunnan muutos [Angelprincess and suicide in a slide: play culture and societal change]. Helsinki: Gaudeamus.

Kirmanen, Tiina. 2000a. Lapsi ja pelko. Sosiaalipsykologinen tutkimus 5-6-vuotiaiden lasten peloista ja pelon hallinnasta. [Children and Fear. Social Psychological Study of 5-6-yearold Children's Fears and Coping with Fears]. Kuopio: Kuopion yliopisto.

---. 2000b. Pelon hallinta ja lapsen turvallisuus [Coping with fear and the security of children]. In: Inhimillinen turvallisuus [Human security], edited by Pauli Niemelä and Anja Riitta Lahikainen, pp. 119-146; Tampere: Vastapaino.

Kodaira, Sachiko Imaizumi. 1998. A Review of Research on Media Violence in Japan. In: Children and Media Violence. Yearbook from the UNESCO International Clearinghouse on Children and Violence on the Screen, edited by Ulla Carlsson and Cecilia von Feilitzen, pp. 81-105. Göteborg: Göteborg University.

Korhonen, Piia and Satu Valkonen. Lapsen minuuden kehitys tietoyhteiskunnassa. [Development of the Child's Self in Information Society.] In: Näkökulmia minuuteen ja identiteettiin [Perspectives to Selfhood and Identity], edited by Mikko Saastamoinen and Pertti Rautio. Tampere: Tampere University Press. Forthcoming.

Kytömäki, Juha. 1999. Täytyy kattoo, jos saa kattoo. Sosiaalipsykologisia näkökulmia varhaisnuorten televisiokokemuksiin [Has to watch TV if it is permitted to watch it. Social psychological viewpoints on subteens' television experiences]. Helsinki: Helsingin yliopisto.

Lahikainen, Anja Riitta, Inger Kraav, Tiina Kirmanen and Leena Maijala. 1995. Lasten turvattomuus Suomessa ja Virossa. 5-12 -vuotiaiden lasten huolten ja pelkojen vertaileva tutkimus. [Children's insecurity in Finland and in Estonia. A comparative study of fears and worries of 5-12-year-old children.] Kuopio: Kuopion yliopisto.

Lahikainen, Anja Riitta, Tiina Kirmanen, Inger Kraav and Merle Taimalu. 2003. Studying Fears in Young Children: Two Interview Methods. Childhood 10(1):83-104.

Lahikainen, Anja Riitta, Jukka Partanen, Mira Roine and Satu Valkonen. 2004. Children Reading and Talking Television. Presentation in the seminar "The culture created by children and children's participation”. Stakes, Helsinki, 17.6. 2004 [cited 17 June 2005]. Available from: http://www.stakes.fi/palvelut/palvelujen_laatu/lapset/In_English/Lahikainen.pdf

Lahikainen, Anja Riitta, Inger Kraav, Tiina Kirmanen and Merle Taimalu. Child-Parent Agreement in the Assessment of Young Children's Fears: A Comparative Perspective. Journal of Cross-cultural Psychology. Forthcoming.

Lehtimäki, Hanna and Juha Suoranta. 2005. Tytöt ja pojat tietoyhteiskunnassa ja sen tutkimuksessa [Girls and boys in the studies of information society]. In: Lapsuus mediamaailmassa. Näkökulmia lasten tietoyhteiskuntaan [Childhood in the media world. Viewpoints on children's information society], edited by Anja Riitta Lahikainen, Pentti Hietala, Tommi Inkinen, Marjatta Kangassalo, Riikka Kivimäki and Frans Mäyrä, pp. 185-199. Helsinki: Gaudeamus.

Livingstone, Sonia, Leen d'Haenens and Uwe Hasebrink. 2001. Childhood in Europe: Context for Comparison. In: Children and their Changing Media Environment. A European Comparative Study, edited by Sonia Livingstone and Moira Bovill, pp. 3-30. Mahwah: Lawrence Erlbaum Associates.

Lull, James. 1990. Inside Family Viewing. Ethnographic Research on Television’s Audiences. London: Routledge. 
Matikkala, Ulla and Anja Riitta Lahikainen. 2005. Pelit, tietokone ja kännykkä lasten sosiaalisissa suhteissa [Games, computers and mobile phones in children's social relations]. In: Lapsuus mediamaailmassa. Näkökulmia lasten tietoyhteiskuntaan [Childhood in the media world. Viewpoints on children's information society], edited by Anja Riitta Lahikainen, Pentti Hietala, Tommi Inkinen, Marjatta Kangassalo, Riikka Kivimäki and Frans Mäyrä, pp. 92-109. Helsinki: Gaudeamus.

Merlo-Flores, Tatiana. 1998. Why Do We Watch Television Violence? Argentine Field Research. In: Children and Media Violence. Yearbook from the UNESCO International Clearinghouse on Children and Violence on the Screen, edited by Ulla Carlsson and Cecilia von Feilitzen, pp. 155-179. Göteborg: Göteborg University.

Ozmert, Elif, Muge Toyran and Kadriye Yurdakok. 2002. Behavioral correlates of television viewing in primary school children evaluated by the child behavior checklist. Archives of Pediatrics \& Adolescent Medicine 156(9):910-914.

Pasquier, Dominique, Carlo Buzzi, Leen d’Haenens and Ulrika Sjöberg. 1998. Family Lifestyles and Media Use Patterns. An Analysis of Domestic Media among Flemish, French, Italian and Swedish Children and Teenagers. European Journal of Communication 13(4):503-519.

Pasquier, Dominique. 2001. Media at Home: Domestic Interactions and Regulation. In: Children and their Changing Media Environment. A European Comparative Study, edited by Sonia Livingstone and Moira Bovill, pp. 161-177. Mahwah: Lawrence Erlbaum Associates.

Phillipson, Chris. 2004. Social Networks and Social Support in Later Life. In: Social Networks and Social Exclusion, edited by Chris Phillipson, Graham Allan and David Morgan, pp. 35-49. Aldershot: Ashgate.

Punch, Samantha. 2002. Research with Children. The Same or Different from Research with Adults? Childhood 9(3):321-341.

Robinson, Thomas N., Marta L. Wilde, Lisa C. Navracruz, Farish K. Haydel and Ann Varady. 2001. Effects of reducing children's television and video game use on aggressive behavior: a randomized controlled trial. Archives of Pediatrics \& Adolescent Medicine 155(1):17-23.

Rosengren, Karl-Erik and Sven Windahl. 1989. TV Use in Childhood and Adolescence. New Jersey: Ablex Norwood.

Rönnberg, Margareta. 1997. TV är bra för barn [TV is good for children]. Stockholm: Ekerlids Förlag.

Strasburger, Victor, S. and Edward Donnerstein. 1999. Children, Adolescents, and the Media: Issues and Solutions. Pediatrics 103(1):129-139.

Suoninen, Annikka. 1993. Televisio lasten elämässä [Television in children’s life]. Nykykulttuurin tutkimusyksikön julkaisuja 37. Jyväskylä: Jyväskylän yliopisto.

---. 2001. The Role of Media in Peer Group Relations. In: Children and their Changing Media Environment. A European Comparative Study, edited by Sonia Livingstone and Moira Bovill, pp. 201-219. Mahwah: Lawrence Erlbaum Associates.

---. 2004. Mediakielitaidon jäljillä: Lapset ja nuoret valikoivina mediankäyttäjinä [Searching for media literacy. Children and adolescents as selective media users]. Nykykulttuurin tutkimuskeskuksen julkaisuja 81. Jyväskylä: Jyväskylän yliopisto.

Suoranta, Juha and Hanna Lehtimäki. 2004. Children in the Information Society. The Case of Finland. New York: Peter Lang.

Süess, Daniel, Annikka Suoninen, Carmelo Garitaonandia, Patxi Juaristi, Riitta Koikkalainen and Jose A. Oleaga. 1998. Media Use and the Relationships of Children and Teenagers with their Peer Groups. European Journal of Communication (13)4:521-538.

Toyran, Muge, Elif Ozmert and Kadriye Yurdakok. 2002. Television viewing and its effect on physical health of school age children. Turkish Journal of Pediatrics 44:194-203. 
Vandewater, Elizabeth A., David S. Bickham, June H. Lee, Hope M. Cummings, Ellen A. Wartella and Victoria J. Rideout. 2005. When Television Is Always On. Heavy Television Exposure and Young Children's Development. American Behavioral Scientist 48(5): 562-577.

Valkonen, Satu, Marjo Pennonen and Anja Riitta Lahikainen. 2005. Televisio pienten lasten arjessa [Television as a part of young children's everyday life]. In: Lapsuus mediamaailmassa. Näkökulmia lasten tietoyhteiskuntaan [Childhood in the media world. Viewpoints on children's information society], edited by Anja Riitta Lahikainen, Pentti Hietala, Tommi Inkinen, Marjatta Kangassalo, Riikka Kivimäki and Frans Mäyrä, pp. 54-91. Helsinki: Gaudeamus.

Viemerö, Vappu. 1986. Relationships between filmed violence and aggression. Reports from the Department of Psychology at Åbo Akademi, Monograph Suplement 4. Turku: Åbo Akademi. 


\section{Appendix I}

Description of the interview method of this study

In this research project ('Children's Well-being and Media in Societal and Cultural Contexts'), all the interviewers (three doctoral students and three graduate students) were trained by the project leader to collect research data. In the interviews, we firstly asked children to create their social network in the form of a target diagram. Children were presented with a diagram of four concentric circles with a smallest circle in the centre representing the child her/himself. Children were then asked to place the pictures of the people they found important in the circles: those whom the child felt were the most closest to her/him, s/he placed in the inner circle, those considered less close but still important were listed in the middle and outer circles. (Compare the use of this method to Phillipson 2004.)

This method enabled us to understand the children's social network and helped children to feel more comfortable with a strange adult (see Lahikainen et al. 2003). Researchers studying children have perceived that such task-based activities enable children to take an active part in generating data and allow them time to think about what they would like to tell the interviewer. Hence, task-based techniques also mitigate the unequal power relationship between the adult and the child which is often seen as a problem in social studies on childhood. (Punch 2002.)

Then, at the beginning of the fear section, we told the children that all people are sometimes afraid of something and feeling fear is fully acceptable. We also emphasized that adults do not know what children are afraid of and this is why we have to address questions directly to them. This introduction to the fear section was then followed by the main question, "What things are you afraid of?". Additional questions were allowed when necessary. The intensity of fear was measured using three different categories (great, average, minimal fear) (see Carpenter 1990). Each time the child reported a fear, s/he was asked to show the fear line which demonstrated how afraid $\mathrm{s} /$ he was in that frightening situation. Children were allowed to talk about their fears as long as they wished. Then, in the picture-aided part of the fear section, eight pictures were shown with a short story about a girl or a boy appearing in the picture (depending on the interviewee's gender). Pictures represented frightening situations and after the each picture, the child was asked: "How does Lisa/Lars feel? Is s/he afraid and what does s/he do afterwards?". The intensity of fear was measured in the same way as in open-ended fear section. (See Lahikainen et al., forthcoming.)

We also asked children if they had ever had bad dreams and what this nightmare was about. Focused questions were allowed when needed. After this, we asked about the children's relation to television. There were five themes to discuss. 1.) Has the child ever seen something frightening on television? 2.) What programs does s/he watch? 3.) What is her/his favorite program and why? 4.) What is bad on TV and why? and 5.) Has s/he ever learnt anything from television and what was it? The purpose of these questions was to examine how possible positive or negative effects of television define children's well-being. At the end of each interview we asked what makes the child happy. Because of the sensitivity of the research topic, it was important to end the interview in supportive and encouraging themes. 


\section{Appendix II}

Questions used in this article (part of the parental questionnaire)

a) The gender of the target child: Boy/Girl.

b) The parents of this child are 1) married 2) cohabiting 3) divorced or separated

4) one parent is dead 5) other, what

c) How is the child's daily care arranged at the moment? 1) at home with the mother/father/other relative 2) day care center or children's private day care 3) other arrangements (e.g. grandmother's place)

d) Parents' socio-economic status (SES) was deduced from the questions concerning their basic education (alternatives being: elementary school/comprehensive school/upper secondary school) and from vocational training (no vocational training/vocational school/polytechnic or university/other, what

1) How many hours is the television on in the family?

Weekdays

Weekends

2) How many hours is the television on when the target child is awake?

Weekdays Weekends

3) How many hours does the child watch television on weekdays?

4) How many hours does the child watch television on Saturdays?

5) How many hours does the child watch television on Sundays?

The following questions have the same response alternatives a) never b) occasionally (1-2 times a month) c) sometimes (1-2 times a week) d) often (3-5 times a week) e) always (daily) )

7) Child watches television alone

8) Parents watch TV with the child

9) Child watches television with peers (friends/siblings)

14) Child watches videos

16) Watches television/videos at bedtime

17) Plays computer or console games

18) Watches children's programs

19) Watches current affairs programs

21) Watches sports

22) Watches adults' TV series

24) Child has a TV-set in her/his room: Yes/No 


\section{Appendix III}

TV viewing of the children with or without a TV-set

\begin{tabular}{|c|c|c|c|c|c|}
\hline \multicolumn{6}{|c|}{ Group Statistics } \\
\hline & $\begin{array}{l}\text { TV set in } \\
\text { childs's } \\
\text { room }\end{array}$ & $\mathrm{N}$ & $\begin{array}{r}\text { Mean } \\
\text { (hours) }\end{array}$ & $\begin{array}{c}\text { Std. } \\
\text { Deviation }\end{array}$ & $\begin{array}{l}\text { Std. Error } \\
\text { Mean }\end{array}$ \\
\hline \multirow{2}{*}{ Open weeks } & yes & 59 & 4.686 & 2.4493 & .3189 \\
\hline & no & 224 & 3.620 & 1.6850 & .1126 \\
\hline \multirow{2}{*}{ Weekends } & yes & 60 & 6.000 & 2.2531 & .2909 \\
\hline & no & 223 & 4.823 & 1.9140 & .1282 \\
\hline \multirow{2}{*}{ When child awake week } & yes & 59 & 3.000 & 1.3551 & .1764 \\
\hline & no & 226 & 2.571 & 2.1337 & .1419 \\
\hline \multirow{2}{*}{ Child awake weekends } & yes & 60 & 4.517 & 2.1745 & .2807 \\
\hline & no & 222 & 3.466 & 1.5501 & .1040 \\
\hline \multirow{2}{*}{ Watches TV week } & yes & 60 & 1.492 & .5930 & .0766 \\
\hline & no & 226 & 1.163 & .4798 & .0319 \\
\hline \multirow{2}{*}{ Saturdays } & yes & 61 & 2.566 & .8779 & .1124 \\
\hline & no & 225 & 1.921 & .7621 & .0508 \\
\hline \multirow{2}{*}{ Sundays } & yes & 61 & 2.336 & .9207 & .1179 \\
\hline & no & 225 & 1.769 & .7308 & .0487 \\
\hline
\end{tabular}




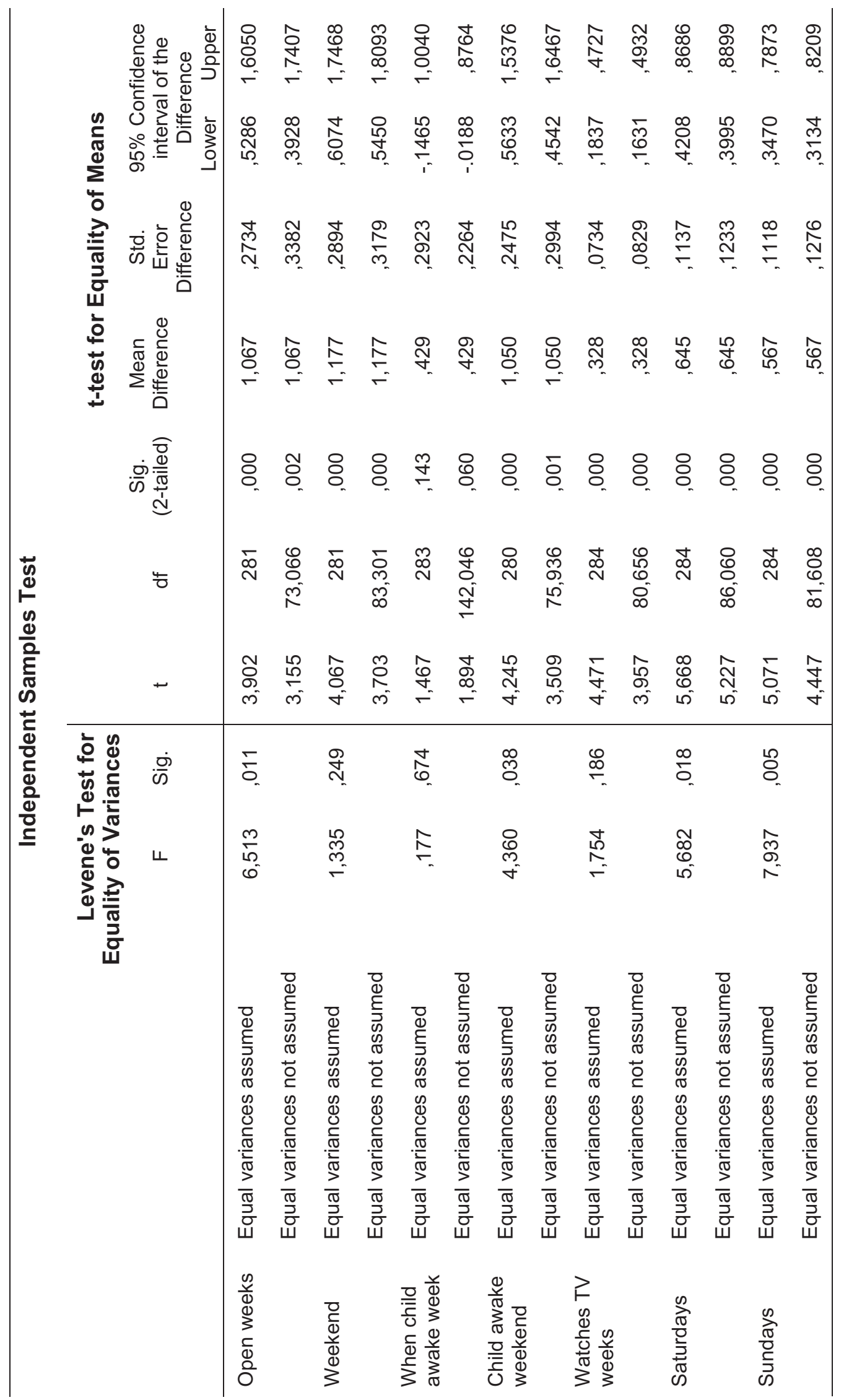

